This is an electronic reprint of the original article. This reprint may differ from the original in pagination and typographic detail.

Author(s): Litmanen, Tapio; Jartti, Tuija; Rantala, Eero

Title: $\quad$ Refining the preconditions of a social licence to operate (SLO) : reflections on citizens' attitudes towards mining in two Finnish regions

Year: $\quad 2016$

Version:

Please cite the original version:

Litmanen, T., Jartti, T., \& Rantala, E. (2016). Refining the preconditions of a social licence to operate (SLO) : reflections on citizens' attitudes towards mining in two Finnish regions. The Extractive Industries and Society, 3(3), 782-792.

https://doi.org/10.1016/j.exis.2016.04.003

All material supplied via JYX is protected by copyright and other intellectual property rights, and duplication or sale of all or part of any of the repository collections is not permitted, except that material may be duplicated by you for your research use or educational purposes in electronic or print form. You must obtain permission for any other use. Electronic or print copies may not be offered, whether for sale or otherwise to anyone who is not an authorised user. 


\title{
Refining the preconditions of a Social Licence to Operate (SLO): Reflections on Citizens' Attitudes Towards Mining in Two Finnish Regions
}

\begin{abstract}
The debate around the social licence to operate (SLO) has been lively in recent years. In its elementary forms, the SLO is seen as interpreted as the social acceptance granted by a community to either a mining project or an exploration project. Our theoretical assumption is that the SLO as a concept is both case-specific and more general, contingent, among other things, upon public opinion. In this study, acceptance is considered as general and anticipatory in the sense that it can act as a precondition for individual SLOs. Our intention is to contribute especially to recent novel research focusing on the more general background and factors contributing to the SLO. Using survey data $(\mathrm{N}=1,064)$, we explore relationships of factors potentially connected to the SLO in two Finnish regions where in the last decade mining has been a growing industry. We are concerned with the connection between the acceptability of mining and six factors measured by nine explanatory variables. The findings show that the six factors investigated do indeed affect acceptance but not in any straightforward manner.
\end{abstract}

Keywords: Social licence to operate, social acceptance, mining, societal prerequisites, public opinion 
Refining the preconditions of a Social Licence to Operate (SLO): Reflections on Citizens' Attitudes Towards Mining in Two Finnish Regions

\section{Introduction}

The importance of the societal acceptance of mining has become apparent to various actors in the sector. In the last 20 years the mining industry has been under pressure to contribute more positively to regional development (IIED 2002, 4; Gibson 2006, 334; Slack 2009, 83; Tuusjärvi 2013, 11). The global image of mining has been negative, with concerns raised in particular about the ability of the industry to manage environmental and social impacts (Clark \& Cook Clark 1999; Hilson 2002; Cademartori 2002; Jenkins \& Yakovleva 2006; Holden \& Jacobson 2007; Holden et al. 2007; Trebeck 2007; Eerola 2008; Holden \& Jacobson 2008; Le Billion \& Levin 2009; Taylor 2011; Urkidi 2011; Akiwumi 2012). The mitigation of the environmental impacts of mining has been approached mainly as a technological and engineering challenge (Clark \& Cook Clark 1999, 190; Solomon et al. 2008, 142; Richards 2009, xxi; Everingham 2012, 92). A growing number of mine managers and executives, however, now recognize that these challenges also require the application of effective policies, and that in addition to complying with legislation and official requirements, it is vital to ensure the social acceptance of their operations (Joyce \& Thomson 2000) or to secure a so-called Social Licence to Operate (SLO) (Franks \& Cohen 2012).

There is now a substantial body of research which explores the challenges surrounding the SLO (Wilburn \& Wilburn 2011; Luning 2012; Eerola \& Ziessler 2013; Owen \& Kemp 2013), in particular, empirical research which has endeavoured to identify factors contributing to its formation. Using survey data, we explore which factors are potentially connected to the SLO in two Finnish regions where in the last decade mining activity has 
expanded. Our intention is to contribute especially to recent novel research that focuses on the more general background and factors contributing to the SLO (e.g. Moffat \& Zhang 2014; Moffat et al. 2014a; Moffat et al. 2014b; Zhang et al. 2015).

Based on the recent social science literature on mining, our theoretical assumption is that SLO as a concept is both case-specific and more generally contingent among other things, upon public opinion (e.g. Gunningham et al. 2004; Prno \& Slocombe 2012). Mason et al. (2014) have stated that the wider population (not only the local residents) has expectations regarding, for example, how the mining industry should act. Such public opinion also affects the acceptability of an individual mining project at the local level and whether or not it is deemed to merit an SLO. However, the attitudes and expectations of the wider population in regard to mining have not been systematically researched to any great degree.

According to Zhang et al. $(2015,1063-1064)$ there has been a tendency in research to explore the factors constituting an SLO at the local level and thus to understand, in particular, the relationship between local communities and certain mining projects. It is important, however, not to only focus on whether individual mining projects have an SLO with their community, but to also look at whether the entire industry operates under a SLO from the public at large. We therefore direct our research towards public opinion, but still keep an emphasis on the regional-cultural ties of acceptability (Wilson 2004; Mononen 2012; Martinez-Fernandez et al. 2012). It is important to pay attention to the historical and social antecedents and the various social, cultural and societal factors underlying the SLO.

The article is structured as follows. First, based on the literature, we present a general overview of SLO. This is followed by a look at the general characteristics of the mining 
sector in Finland. These characteristics can be seen as an important part of the societal context surrounding and affecting the formation of individual SLOs. Then, in the third section, the methodological issues of the study are addressed. In the fourth section, we discuss the factors potentially contributing to the acceptance of mining for certain substances. In the fifth and sixth sections, the findings of the analysis are presented: first, the Kainuu data are examined, after which the Lapland data are interrogated. In the final two sections, we first summarize the findings and then compare our results to the main observations from earlier research.

\section{A Critical understanding of the SLO}

The concept of the SLO originally developed as a response on the part of industry to rising criticism and opposition to mining projects, and thus as a mechanism to ensure the viability of the sector (Owen \& Kemp 2013, 29). The concept surfaced in 1997 and quickly became an essential part of the vocabulary of the mining industry, civil society and mining communities (Thomson \& Boutilier 2011a, 1779).

The SLO is usually taken to be site-specific (Thomson \& Boutilier 2011a, 1781). It then refers, when simplified, to the social acceptance crucial to the continuity of certain exploration and mining projects (Franks \& Cohen 2012, 1229; Mason et al. 2014, 1). At the level of individual mining projects, the SLO has its roots in the beliefs, perceptions and opinions held by the local population and other stakeholders about a specific mining project. Thus SLO is typically seen to be granted by the community. (Thomson \& Joyce 2008; Thomson \& Boutilier 2011a, 1779, 1781.) Thomson and Boutilier (2011a, 1781) use 'community' to refer to a network of stakeholders including the participation of individuals, 
groups and/or organizations that might not necessarily be part of a geographic community and recognize the intrinsically heterogeneous nature of communities. A stakeholder is defined as an individual, group or organization that either can affect or is affected by the mining operation (Thomson \& Boutilier 2011a, 1781). Franks and Cohen (2012, 1231-1232) likewise stress the necessity of acknowledging that those located in the vicinity of an operation (communities of place) as well as those with legitimate but perhaps less immediate interests (communities of interest) are both crucial informants in the shaping of a SLO. Gunningham et al. $(2004,308)$ also define SLO as 'the demands on and expectations for a business enterprise that emerge from neighborhoods, environmental groups, community members, and other elements of the surrounding civil society'. Thus, according to Gunningham et al. (2004, 313), SLO is based on the extent 'to which a corporation and its activities meet the expectations of local communities, the wider society, and various constituent groups'.

A SLO is perceived to exist when the local residents and other stakeholders have expressed their acceptance and/or widespread approval for some prospecting project or mining operation (Thomson \& Boutilier 2011a, 1779; Prno \& Slocombe 2012, 346; Moffat \& Zhang 2014, 61). It has been emphasized that SLOs may differ in their strength, reflecting various levels of social approval and acceptance (see Thomson \& Boutilier 2011a, 1779). The distinction between approval and acceptance reflects the two levels of the SLO: a lower level of acceptance and a higher level of approval (Thomson \& Boutilier 2011a, 1779). At the level of acceptance, the mining operation is merely tolerated. A higher level of SLO pertains when the mining operation is approved of and the continuation of the activity is encouraged. The highest level of SLO is seen in the community's perception of the operation as being integral to their communal identity and values, and thus in a feeling of having a vested interest in the 
outcomes of the project. Higher levels of SLO are achieved gradually as an operation establishes legitimacy, credibility and trust. (Thomson \& Joyce 2008; Thomson \& Boutilier 2011a, 1784-1786; Franks \& Cohen 2012, 1232.) The interactive process by which a SLO is negotiated is contextually specific, dynamic and non-linear. Stakeholders' perceptions, beliefs and opinions depend, for example, on the operation in question and are subject to change as new information is acquired. (Thomson \& Boutilier 2011a, 1779; Franks \& Cohen 2012, 1232.) Thus, SLO has to be earned and maintained because it may be withdrawn at any stage of the operation (Thomson \& Boutilier 2011a, 1779). Researchers also stress the significance of the technology used. It then emerges that the SLO evolves in the overall interactive entity and is comprised of different mining operations, technologies and communities (Franks et al. 2010, 19; Franks \& Cohen 2012).

Although an accurate description of comprehensive rules for the formation of an SLO may never be feasible, scrutinizing the background factors contributing to its formation helps to understand what underlies it. For example, Prno (2013) bases his view on four case studies. In light of these he claims that the SLO is contingent upon five important factors: (1) sensitivity to context, (2) capability to interact, (3) extensive attention to sustainable development, (4) promotion of the benefits and active participation and (5) the ability to adapt to a complex reality. Moffat and Zhang (2014, 64-68) likewise tested an SLO model, with its elements being the following: (1) impact on social infrastructure, (2) number of contacts, (3) quality of contacts and (4) envisaged procedural fairness. Their study showed that the impact on social infrastructure, the quality of contacts between members of the local community and representatives of the mining company and the envisaged so-called procedural fairness were significant predictors of trust in the mining company, and this, in turn, was connected to the social acceptance of mining. 
On the basis of their study, Thomson and Boutilier $(2011 b, 5)$ divide the SLO into four factors: economic justification, socio-political justification, interactive trust and institutional trust. Ziessler-Korppi $(2013,35)$ brings together aspects which mining companies should consider in the acquisition of the SLO: (1) image management; (2) the will to comprehend the local culture, language and history; (3) respect for the local population; (4) enlightening local residents about the project; (5) building local partnership; (6) developing local capability for action; (7) maintaining interactive communication throughout the project; and (8) preserving trust.

Owen and Kemp $(2013,31)$ stress that the concept of SLO can be used at a range of societal levels from the macro to the local. They state that contemporary use in mining, however, mainly relates SLO to the perceptions of locally-impacted communities about a company's activities and the impacts of those activities on the local culture, environment, economy and livelihoods. Thus, SLO is often underpinned by an understanding according to which local perceptions and responses are seen as determining a company's ability to access the resources needed for a particular operation (Owen \& Kemp 2013, 31). Prno and Slocombe $(2012,347)$ also point out that even though SLO may be issued by society as a whole (e.g. government, communities, the general public, media), local communities are often key actors in the process due to their proximity to the projects, their sensitivity to impacts and their ability to influence project outcomes.

Research on SLO has traditionally focused specifically on local communities directly affected by mining operations, and there has been a lack of systematic research exploring attitudes towards mining among the public at large or the expectations of society as a whole 
(Mason et al. 2014, 1-2; see also Zhang et al. 2015). Zhang and Moffat (2015, 25-26), for example, emphasized that while there have been extensive case studies examining the nature of different impacts and benefits arising from mining operations, there has been a lack of systematic examination into how these issues are perceived at the national level and how these perceptions relate to the acceptance of the industry by the public at large. The existing research on the public opinion of mining is quite fragmented; often in the form of opinion polls and perception studies (e.g. Prospectors and Developers Association 2009; Fast Consulting 2013; Saskatchewan Mining Association 2013; Sacome 2014; World Bank Institute 2014). However, there is currently a growing interest in more systematic measurement of national attitudes towards mining and the comparison of these attitudes (e.g. Moffat et al. 2014a; Moffat et al. 2014b; Zhang et al. 2015).

In this paper, we explore the connection between the acceptability of mining for certain substances and six factors measured by nine explanatory variables. This acceptance is seen as a precondition and a basis for individual SLOs. Acceptance is considered as general and anticipatory in the sense that it does not relate to any individual mining project. Instead, it is about how ready the people in a certain geographical area would be in principle to accepting mining for different substances. Acceptance may serve, and, according to our hypothesis, does indeed serve, as a precondition for individual SLOs in the sense that the more widespread the acceptance of mining for different substances is, the better are the chances of mining companies earning a SLO to operate for their projects.

We hypothesize a connection between acceptance of mining for certain substances and the following six factors: (1) environmental attitudes, (2) perception of the need for and disadvantages of mining, (3) familiarity with the mining industry and estimating how much is 
known about mining, (4) trust in officialdom, (5) trust in environmental legislation and (6) attitudes towards foreign mining companies. The exact variables by which these factors are measured are described in detail later in the paper.

Our correlational examination rests on three premises. First, in the original survey the respondents were asked not only about the acceptability of mining for different substances in Finland in general but also about the acceptability of mining for the same substances if these activities were to take place in the respondent's home municipality (see Jartti et al. 2014, 6597). However, in this paper we focus only on the respondents' views on the acceptance of mining for certain substances at the level of Finland in general. Second, we were interested in how the factors of interest were connected to the acceptability of the various substances extracted. Although in the original questionnaire these substances extracted were divided very precisely, in our analysis we combined them into three groups: (1) metals and minerals ${ }^{1}$, (2) uranium and (3) rock material (later in the text referred to as aggregates ${ }^{2}$ ) and natural stones (e.g. granite, soapstone). We also included two of the original four regions researched. The reasons for choosing only two out of four are explained in the data, method and analysis section.

\section{Preconditions for SLOs in the Finnish mining sector}

\footnotetext{
${ }^{1}$ The group of metals and minerals includes precious metals (e.g. gold, silver), base metals (e.g. nickel, iron, copper), high tech metals (e.g. lithium) and industrial minerals (e.g. limestone, calcite, dolomite, talc).

2 The term aggregate can be applied to either crushed rock or gravel and sand (Finland's Minerals Strategy 2010, 9).
} 
In the Finnish mining history one can detect signs of historical changes in national economic policy. Both economic and mining history can be characterized as being premises for the formation of individual SLOs. Generally, in Finnish economic history the pivotal role has been played by state-led modernization and industrialization policy and so-called state capitalism (Lindborg 1996, 36-37; Kuisma 1997, 14; Kuisma 2004, 11-12; see also Kuisma 1985; Kuisma 1989). The tenets of this economic system - economic nationalism and trust in state-led economic policy - began to crumble in the 1980s when liberal ideas spread to Finland from the wider world (Kuisma 2004; Kuisma 2013, 214). Even though the 1970s and 1980s signaled a partial shift from state-led industrial policy, subventions continued in the mining industry, as did restrictions on competition and support for selected industries and exports (Kuisma 1985; Lindborg 1996, 189; Särkikoski 2005). By the end of the 1980s the mining sector had begun to open up (Kuisma 1989, 221-222; Lindborg 1996, 150-151). The 1990s can be seen in many ways as a transitional period for the Finnish and Nordic mining industries, as markets opened up to European enterprises when the EEC agreement necessitated an amendment to the Finnish mining legislation in 1994 (Lindborg 1996, 151). Despite fluctuations in mining, the mining cluster has been an important industry in the Nordic countries. At the end of the 1990s it accounted for 1.5 per cent of Finnish GDP (Lindborg 1996, 32). However, the actual inrush to Finland of foreign ore prospecting and mining companies only began in 2003-2004 when there was a steep increase in world prices for metals (Hernesniemi et al. 2011, 137). The boom attracted several domestic and foreign exploration and mining companies, and several new metal mines were opened in the early 2010s. This is in stark contrast to the downturn the mining industry in Finland had been suffering in the 1990s. As a result of the rapid increase in mining and exploration, recent environmental problems and the inrush of foreign mining companies to Finland, citizens' fears about and opposition to mining have surfaced increasingly in the twenty-first century 
(Tuusjärvi 2013, 18-19). The reformed legislation on mining (Mining Act 621/2011) increased the attention to be paid to the environmental and societal aspects of mining and increased the compensation to be paid to property owners (Tuusjärvi 2013, 18-19).

Today in Finland the extraction business is comprised of the mining industry, the aggregate industry and the natural stone industry. The mining industry entails quarrying for metal ores and industrial minerals. The minerals sector, in addition to the mining industry and the extraction and processing of aggregates and natural stones, also includes those enterprises which produce the equipment needed in mining, technology and services. Others involved in the minerals sector are those who process minerals, research institutes, universities, polytechnics and, for example, non-governmental organizations. (Finland's Minerals Strategy 2010, 8; Hernesniemi et al. 2011, 11; MEE 2013, 12.) It has been calculated that the mineral cluster in Finland employs over 16,200 people, and if the foreign personnel of equipment manufacturers are included, the cluster directly employs 32,500 people. The cumulative employment effect in Finland is 25,000 people, and, if foreign activities are included, then it is 50,000. (Hernesniemi et al. 2011, 11-12.) In 2012 there were 12 mines mining metallic ores and 29 mines or quarries for industrial minerals in Finland. Furthermore, 10-15 significant new ventures were in the planning stage, either for new mines or extensions to existing ones. (Hernesniemi et al. 2011; Uusisuo 2012a, 3-6, 14; Uusisuo 2012b, 19-21; Kokko 2013, 15-16.) The increased mining activity in Finland caught the attention of officials and decision-makers at the turn of the 2010s (Sitra 2009; Finland's Minerals Strategy 2010; MEE 2010, 2013).

\section{Data, methods and analysis}


The original research data includes observations from four regions in Finland: Uusimaa, North Karelia, Kainuu and Finnish Lapland. ${ }^{3}$ The last three of these have seen a growth in mining activity since the early 2000s. Uusimaa, by contrast, is a major conurbation that has not seen a similar mining boom as the other three regions in the last decade. In the correlation analysis, however, we concentrate on only two important mining regions, namely Kainuu and Lapland (see Figure 1). Our specific focus on these particular mining regions is justified since, in spite of the global nature of mining, mines attach themselves to localities, geographical areas and influence their prosperity. For example, the economic effects of major mining operations are considerable, both for the regional and the national economy (Törmä \& Reini 2009).

\footnotetext{
${ }^{3}$ This article is based on our earlier study (see Jartti et al. 2014) in which the data and bias analysis are reported in greater detail.
} 


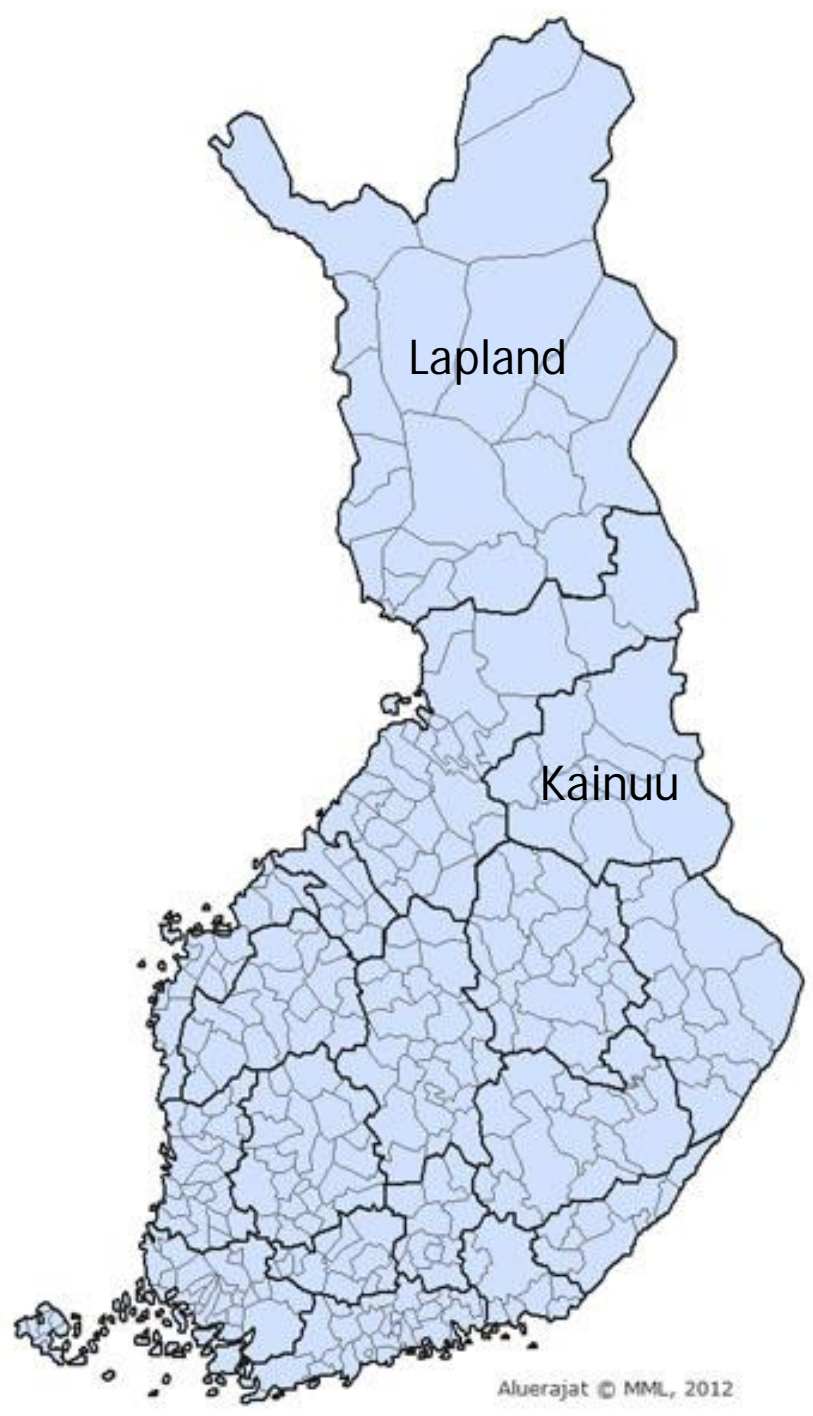

Figure 1. Targeted mining regions in Finland: Lapland and Kainuu ${ }^{4}$

Table 1 presents the sample sizes by region and as a whole. It also provides the numbers of questionnaires received which were eligible for analysis and the response rates by region. The sample comprises 3,200 people and was gathered from the Finnish Population Register by simple random sampling at the end of 2011. The survey was conducted at the beginning of 2012; the first round in January and a follow-on round in February. The questionnaire was

\footnotetext{
${ }^{4}$ Source: National Land Survey of Finland (NLS) \& the Association of Finnish Local and Regional Authorities: http://www.kunnat.net/fi/tietopankit/tilastot/aluejaot/Sivut/default.aspx)
} 
sent out as a traditional postal enquiry. In Uusimaa the questionnaire was sent to 500 people and in North Karelia, Kainuu and Lapland to 900 people in each.

Table 1. Sample sizes, numbers of responses eligible for analysis and response rates by region

\begin{tabular}{|l|l|l|}
\hline Region & Sample & $\begin{array}{l}\text { Returned questionnaires eligible for } \\
\text { analysis and response rates }\end{array}$ \\
\hline Uusimaa & 500 & $131(26 \%)$ \\
\hline North Karelia & 900 & $279(31 \%)$ \\
\hline Kainuu & 900 & $356(40 \%)$ \\
\hline Lapland & 900 & $298(33 \%)$ \\
\hline Total & $\mathbf{3 2 0 0}$ & $\mathbf{1 0 6 4 ( 3 3 \% )}$ \\
\hline
\end{tabular}

The respondents from the selected target regions were residents aged 18-75. In spite of this age limit, in the data there are a few respondents who reported their age to be over 75 ; there are four such people ${ }^{5}$ who were not removed from the analyses. A total of 1,064 eligible questionnaires were received with respect to the sample as a whole and the response rate was 33 per cent. In Kainuu the response rate was 40 per cent with 356 responses, and the response rate from Lapland was 33 per cent with 298 questionnaires returned. The highest response rate was from Kainuu and the lowest from Uusimaa. The response rates are not very high, but fairly normal for conventional postal surveys. For example, Suopajärvi $(2013,27)$ observed that in postal surveys evaluating the social impacts of mining conducted in Northern Finland,

\footnotetext{
${ }^{5}$ Calculated according to the time of sampling (December 2011). The observations outside of the age limit (1875 years) were in North Karelia (one born in 1931) and Kainuu (two individuals born in 1933 and one in 1935).
} 
the response rates varied between 34 per cent and 43 per cent. In addition, no alarming distortions were found in the data used in this paper when the representativeness was checked in regard to socio-demographic background factors (see Jartti et al. 2014, 56-59, 226-229).

Correlation analysis is used to ascertain what variables are connected to the acceptance of mining for the formed three groups of extractives based on the responses from Kainuu and Lapland. Our adjuvant method in the creation of sum variables was factor and principal component analysis. All the variables used in the correlation analysis are also described by their means in the regions of interest.

\section{Factors potentially connected to the acceptability of mining}

The test variables used in the correlation analysis of the acceptance of mining for the three groups of extractives were connected to the following:

- environmental attitudes,

- perceptions of the necessity and disadvantages of mining,

- familiarity with the mining branch and an estimation of the respondent's own knowledge of mining,

- trust in officialdom in monitoring the environmental effects of mining,

- trust in the national environmental legislation, and

- attitude towards the acceptability of mining undertaken in Finland by foreign mining companies.

Environmental attitudes were measured by two variables, both of them sum variables. The first concerned environmental protection and an attitude which stresses caring for the 
environment and measured this characteristic incrementally on a scale of $1-5 .^{6}$ The other sum variable related to environmental attitudes and environmental protection concerns an indifferent attitude that stresses shifting the responsibility for the environment onto others. ${ }^{7}$ This attitude was measured incrementally on a scale of 1-5.

Two of the measures of interest concerned perceptions of the disadvantages and benefits of mining for Eastern and Northern Finland. These individual Likert-scale variables were as follows: 'Mining is necessary to the vitality of Eastern and Northern Finland' and 'Mining is detrimental to the other development of Eastern and Northern Finland'. The response options to these were on a scale of 1-5 (completely disagree - completely agree).

Knowledge of the mining branch was measured with two different variables, one of which was a sum variable and the other a single statement. The sum variable combined knowledge of different metal mines operating in Finland and measured on a scale of 1-3 the respondent's

\footnotetext{
${ }^{6}$ The sum variable was constructed on the basis of factor and principal component analysis by which a group of variables containing various statements on the environment and environmental protection was investigated. The analyses yielded two factors and principal components from which the one presented here is the first. (for more detail see Jartti et al. 2014). The sum variable was constructed of the following Likert-type statements: (1) I am worried about environmental matters, (2) I do what is right for the environment even though it may cost more and take more time, (3) Production branches which maintain our standard of living but which entail environmental risks should not be outsourced to countries whose environmental legislation is inadequate and (4) Society should intervene in environmental problems with strict guidance. The response options to these statements were after an inversion on a scale 1-5/completely disagree-completely agree. The sum variable was constructed with the SPSS MEAN function and under the condition that there should be a response to at least half of the statements. The value of Cronbach's Alpha for the variables was $0.634, \mathrm{~N}=1029$ and it was calculated for the entire data with no division into regions.

${ }^{7}$ The sum variable was constructed on the basis of factor and principal component analysis through which a group of variables which contained various statements related to the environment and environmental protection was examined from the questionnaire. The analyses yielded two factors and principal components, the second of which is presented here (for more detail see Jartti et al. 2014). The sum variable was constructed of the following Likert-type statements: (1) It is just too difficult for an individual to do anything for the good of the environment, (2) It is not my business to take care of the environment, (3) Modern science will solve environmental problems without any changes at all in our way of life, (4) It is for society to solve environmental problems, not individuals. The response options to the statements were after inversion on a scale 1-5/completely disagree-completely agree. The sum variable was constructed with SPSS MEAN function and conditioned in such a way that there should be a response to at least half of the measures. Cronbach's Alpha for the variables was $0.572, \mathrm{~N}=1031$, calculated for the whole data with no division into regions.
} 
familiarity with different metal ore mines operating in Finland. ${ }^{8}$ In the individual statement of interest, respondents were instead asked to consider whether they are sufficiently well informed about mining on a scale of 1-5 (completely disagree - completely agree).

Trust in the environmental legislation was measured with one statement, 'The environmental legislation in Finland guarantees that mining does not cause significant environmental and health hazards', which is a Likert-type statement with a scale of 1-5 (completely disagree completely agree). Likewise, trust in officialdom was measured with a single Likert-type statement, 'In Finland the officials reliably monitor the environmental effects of mining', with a scale of 1-5 (completely disagree -completely agree).

The acceptability of mining conducted by foreign mining companies in Finland was measured with a single Likert-type statement, 'I accept foreign mining companies engaging in mining in Finland', with a scale of 1-5 (completely disagree - completely agree).

Table 2 presents the means of the key variables used in the correlation analysis by region.

Table 2. Means by region

\begin{tabular}{|c|c|c|}
\hline Variables/Regions & Kainuu & Lapland \\
\hline Extraction of energy resources (uranium) acceptable in Finland (completely \\
disagree - completely agree, 1-5) & 2.9 & 2.8 \\
\hline $\begin{array}{c}\text { Extraction of metals and industrial minerals acceptable in Finland (completely } \\
\text { disagree - completely agree, 1-5) }\end{array}$ & 4.3 & 4.4 \\
\hline
\end{tabular}

\footnotetext{
${ }^{8}$ The sum variable was constructed through 11 statements that elicited how familiar different metal mines in Finland were to the respondent on a scale 1-3 (not familiar at all - very familiar). The mines were Suurikuusikko, Kevitsa, Pahtavaara, Elijärvi, Talvivaara, Hitura, Pyhäsalmi, Pampalo, Orivesi, Jokisivu and Kylylahti. The variable was constructed with the SPSS MEAN function, and the condition imposed was that at least half of the variables should be answered if the person was to be included in the sum variable. Cronbach's Alpha for the sum variable was $0.802, \mathrm{~N}=1005$ and it was calculated for the whole data with no division into regions.
} 


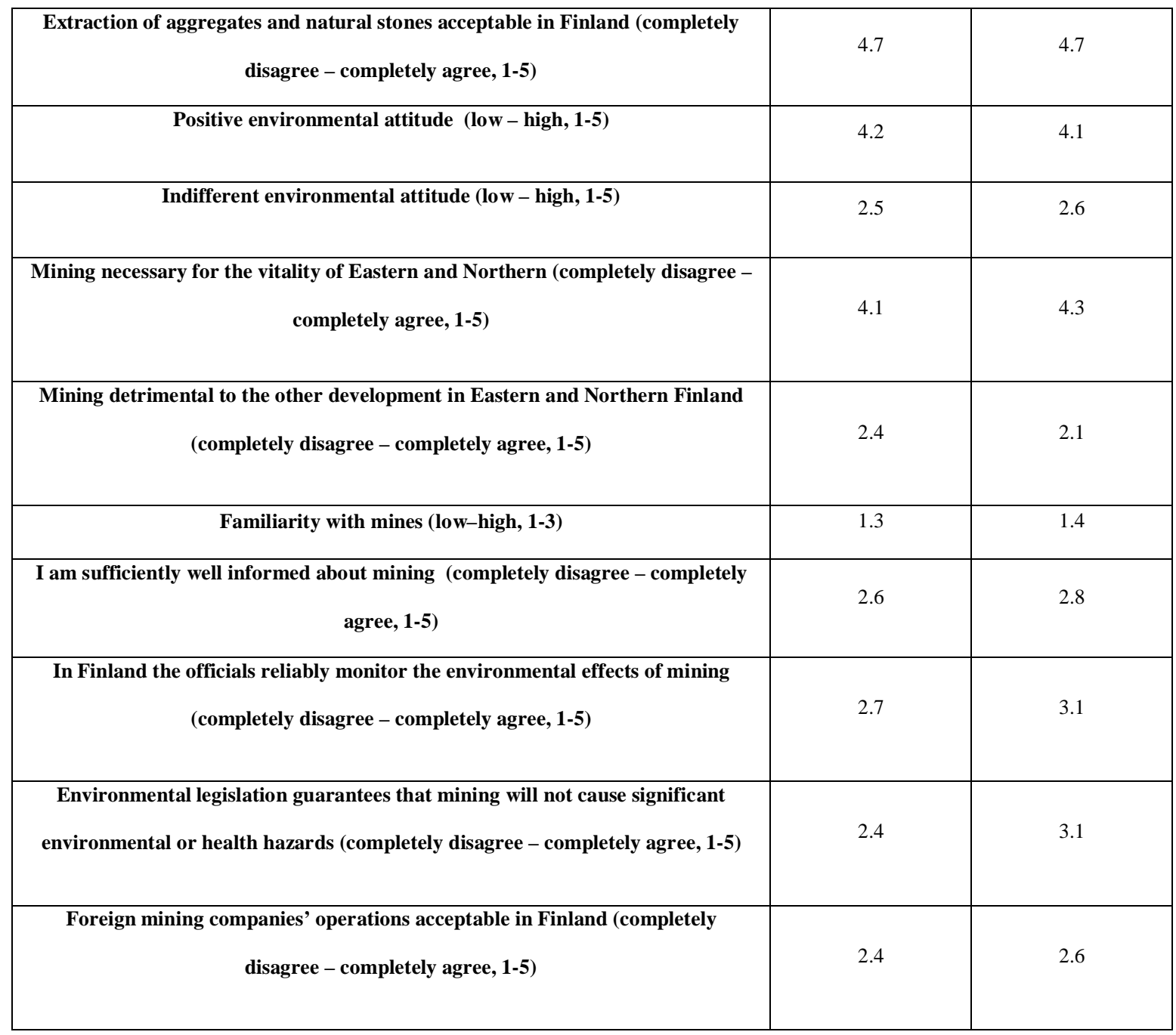

\section{Factors influencing acceptability in Kainuu}

Among the environmental attitudes explored, only the attitude emphasizing environmental protection and caring for the environment is statistically significant in Kainuu, having a negative connection to the acceptability of mining for uranium in Finland $(-0.318, \mathrm{p}<0.001)$. People who are more concerned about environmental protection are less inclined to accept mining for uranium in Finland. The attitude emphasizing environmental protection and caring for the environment is not unambiguously connected to the acceptability of mining for the other substances examined here. There is also no statistically significant connection between 
an indifferent attitude to the environment and the acceptability of mining for any substance of interest (see Table 3)

Table 3. Acceptability of mining in Kainuu

\begin{tabular}{|c|c|c|c|c|}
\hline & & $\begin{array}{l}\text { Extraction of energy } \\
\text { resources } \\
\text { (uranium) } \\
\text { acceptable in } \\
\text { Finland }\end{array}$ & $\begin{array}{l}\text { Extraction of } \\
\text { metals and } \\
\text { industrial } \\
\text { minerals } \\
\text { acceptable in } \\
\text { Finland }\end{array}$ & $\begin{array}{l}\text { Extraction of } \\
\text { aggregates and } \\
\text { natural stones } \\
\text { acceptable in } \\
\text { Finland }\end{array}$ \\
\hline Positive environmental attitude (low - high) & $\begin{array}{l}\text { Correlation } \\
\text { Significance (2-way) } \\
\mathrm{N}\end{array}$ & $\begin{array}{l}-.318 \\
.000 \\
341\end{array}$ & $\begin{array}{l}-.058 \\
.288 \\
343\end{array}$ & $\begin{array}{l}.094 \\
.080 \\
345\end{array}$ \\
\hline Indifferent environmental attitude (low - high) & $\begin{array}{l}\text { Correlation } \\
\text { Significance (2-way.) } \\
\mathrm{N}\end{array}$ & $\begin{array}{l}.044 \\
.417 \\
341\end{array}$ & $\begin{array}{l}-.015 \\
.782 \\
343\end{array}$ & $\begin{array}{l}.039 \\
.469 \\
345\end{array}$ \\
\hline Familiarity with mines (low - high) & $\begin{array}{l}\text { Correlation } \\
\text { Significance (2-way) } \\
\mathrm{N}\end{array}$ & $\begin{array}{l}.102 \\
.059 \\
343\end{array}$ & $\begin{array}{l}.087 \\
.106 \\
345\end{array}$ & $\begin{array}{l}-.001 \\
.987 \\
347\end{array}$ \\
\hline $\begin{array}{l}\text { I am sufficiently well informed about mining } \\
\text { (completely disagree - completely agree) }\end{array}$ & $\begin{array}{l}\text { Correlation } \\
\text { Significance (2-way.) } \\
\mathrm{N}\end{array}$ & $\begin{array}{l}.086 \\
.111 \\
348\end{array}$ & $\begin{array}{l}.062 \\
.248 \\
349\end{array}$ & $\begin{array}{l}.064 \\
.234 \\
351\end{array}$ \\
\hline $\begin{array}{l}\text { Mining necessary for the vitality of Eastern and } \\
\text { Northern Finland (completely disagree - } \\
\text { completely agree) }\end{array}$ & $\begin{array}{l}\text { Correlation } \\
\text { Significance (2-way) } \\
\mathrm{N}\end{array}$ & $\begin{array}{l}.508 \\
.000 \\
346\end{array}$ & $\begin{array}{l}.589 \\
.000 \\
347\end{array}$ & $\begin{array}{l}.298 \\
.000 \\
349\end{array}$ \\
\hline $\begin{array}{l}\text { Mining detrimental to the other development in } \\
\text { Eastern and Northern Finland (completely } \\
\text { disagree - completely agree) }\end{array}$ & $\begin{array}{l}\text { Correlation } \\
\text { Significance (2-way) } \\
\mathrm{N}\end{array}$ & $\begin{array}{l}-.468 \\
.000 \\
340\end{array}$ & $\begin{array}{l}-.445 \\
.000 \\
342\end{array}$ & $\begin{array}{l}-.190 \\
.000 \\
343\end{array}$ \\
\hline
\end{tabular}

Of the variables concerning the respondent's knowledge about mining and familiarity with metal ore mines in Finland, none reveal any statistically significant connection to the acceptability of mining for the substances studied ( $>$ >.05) (see Table 3). Clear connections were, however, found between variables stressing the acceptability of mining and the benefits 
and drawbacks of mining for Eastern and Northern Finland. Respondents who stressed the drawbacks are overall more critically disposed (correlations between -0.190 and -0.468 , $\mathrm{p}<0.001$ ) to mining for the substances studied in Finland, and those stressing the necessity more positively disposed (correlations $0.298-0.589, \mathrm{p}<0.001$ ). Stressing benefits and drawbacks is more strongly and clearly connected to the acceptability of quarrying for metals and minerals and uranium mining than for aggregates and natural stones. The correlations are high, with one moderate exception. (see Table 4)

Table 4. Correlation between trust in environmental legislation and officialdom with acceptability

\begin{tabular}{|c|c|c|c|c|}
\hline & & $\begin{array}{l}\text { Extraction of energy } \\
\text { resources (uranium) } \\
\text { acceptable in Finland }\end{array}$ & $\begin{array}{l}\text { Extraction of metals } \\
\text { and industrial } \\
\text { minerals acceptable in } \\
\text { Finland }\end{array}$ & $\begin{array}{l}\text { Extraction of } \\
\text { aggregates and } \\
\text { natural stones } \\
\text { acceptable in Finland }\end{array}$ \\
\hline $\begin{array}{l}\text { In Finland the officials reliably monitor } \\
\text { the environmental effects of mining } \\
\text { (completely disagree - completely agree) }\end{array}$ & $\begin{array}{l}\text { Correlation } \\
\text { Significance } \\
\text { (2-way.) } \\
\mathrm{N}\end{array}$ & .000 & .000 & $\begin{array}{l}.003 \\
351\end{array}$ \\
\hline $\begin{array}{l}\text { Environmental legislation guarantees that } \\
\text { mining will not cause significant } \\
\text { environmental or health hazards } \\
\text { (completely disagree }- \text { completely agree) }\end{array}$ & $\begin{array}{l}\text { Correlation } \\
\text { Significance } \\
\text { (2-way.) } \\
\mathrm{N}\end{array}$ & .490 & .370 & .162 \\
\hline
\end{tabular}

In Kainuu the results generally show that those respondents placing more trust in the environmental legislation and monitoring by officialdom are also more positively disposed towards mining for the substances studied. With the exception of quarrying in Finland for aggregates and natural stones the strengths of the correlations are over 0.3 and statistically highly significant $(\mathrm{p}<0.001)$. The correlations between the acceptability of quarrying for aggregates and natural stones at the level of Finland and the variables having to do with trust 
elicited are of the order of 0.16 and statistically significant $(\mathrm{p}<0.01)$. These connections are moderate but not as obvious as for the other substances examined (see Table 5)

Table 5. Correlation between the acceptance of the operations of foreign mining companies and the acceptability of mining for different substances

\begin{tabular}{|l|l|l|l|l|}
\hline & & $\begin{array}{l}\text { Extraction of energy } \\
\text { resources (uranium) } \\
\text { acceptable in Finland }\end{array}$ & $\begin{array}{l}\text { Extraction of metals and } \\
\text { industrial minerals } \\
\text { acceptable in Finland }\end{array}$ & $\begin{array}{l}\text { Extraction of aggregates } \\
\text { and natural stones } \\
\text { acceptable in Finland }\end{array}$ \\
\hline $\begin{array}{l}\text { Foreign mining companies' } \\
\text { operations acceptable in Finland } \\
\text { (completely disagree - completely }\end{array}$ & $\begin{array}{l}\text { Correlation } \\
\text { Significance } \\
\text { agree) }\end{array}$ & .398 & .320 & .026 \\
\hline
\end{tabular}

The results for Kainuu show that people more readily accepting the operations of foreign mining companies in Finland are also more inclined to accept the extraction of uranium and metals and minerals in Finland. The correlations are strong, over 0.3 and statistically highly significant $(\mathrm{p}<0.001)$. No connection is to be found between the acceptability of mining in Finland for aggregates and natural stones and the acceptability of the operations of foreign mining companies (p>.05). (see Table 5)

\section{Factors influencing acceptability in Lapland}

In Lapland, among the variables relating to the environment only the variable stressing the protection of and caring for the environment is connected to the acceptability of mining at the level of Finland. The respondents in Lapland taking environmental protection more seriously are more negatively disposed towards the extraction of uranium $(-0.398, \mathrm{p}<0.001)$ and also towards the extraction of metals and minerals $(-0.197 . \mathrm{p}=0.001)$ in Finland. The connection 
between the attitude stressing environmental protection and the acceptability of mining for uranium is strong and clear, although the connection between the acceptability of quarrying for metals and minerals and the attitude stressing environmental protection is also fairly strong (see Table 6)

Table 6. Acceptability of mining operations in Lapland

\begin{tabular}{|c|c|c|c|c|}
\hline & & $\begin{array}{l}\text { Extraction of } \\
\text { energy resources } \\
\text { (uranium) } \\
\text { acceptable in } \\
\text { Finland }\end{array}$ & $\begin{array}{l}\text { Extraction of metals } \\
\text { and industrial } \\
\text { minerals acceptable } \\
\text { in Finland }\end{array}$ & $\begin{array}{l}\text { Extraction of } \\
\text { aggregates and } \\
\text { natural stones } \\
\text { acceptable in } \\
\text { Finland }\end{array}$ \\
\hline Positive environmental attitude (low - high) & $\begin{array}{l}\text { Correlation } \\
\text { Significance (2-way) } \\
\mathrm{N}\end{array}$ & $\begin{array}{l}-.398 \\
.000 \\
289\end{array}$ & $\begin{array}{l}-.197 \\
.001 \\
289\end{array}$ & $\begin{array}{l}.023 \\
.692 \\
289\end{array}$ \\
\hline $\begin{array}{l}\text { Indifferent environmental attitude (low - } \\
\text { high) }\end{array}$ & $\begin{array}{l}\text { Correlation } \\
\text { Significance (2-way) } \\
\text { N }\end{array}$ & $\begin{array}{l}.107 \\
.069 \\
287\end{array}$ & $\begin{array}{l}.066 \\
.264 \\
287\end{array}$ & $\begin{array}{l}-.022 \\
.711 \\
287\end{array}$ \\
\hline Familiarity with mines (low - high) & $\begin{array}{l}\text { Correlation } \\
\text { Significance (2-way) } \\
\mathrm{N}\end{array}$ & $\begin{array}{l}.155 \\
.008 \\
292\end{array}$ & $\begin{array}{l}.194 \\
.001 \\
292\end{array}$ & $\begin{array}{l}.119 \\
.042 \\
292\end{array}$ \\
\hline $\begin{array}{l}\text { I am sufficiently well informed about } \\
\text { mining (completely disagree - completely } \\
\text { agree) }\end{array}$ & $\begin{array}{l}\text { Correlation } \\
\text { Significance (2-way.) } \\
\text { N }\end{array}$ & $\begin{array}{l}.151 \\
.010 \\
291\end{array}$ & $\begin{array}{l}.109 \\
.062 \\
291\end{array}$ & .094 \\
\hline $\begin{array}{l}\text { Mining is needed for the vitality of Eastern } \\
\text { and Northern Finland (completely disagree } \\
\text { - completely agree) }\end{array}$ & $\begin{array}{l}\text { Correlation } \\
\text { Significance (2-way) } \\
\text { N }\end{array}$ & $\begin{array}{l}.339 \\
.000 \\
290\end{array}$ & $\begin{array}{l}.452 \\
.000 \\
290\end{array}$ & .218 \\
\hline $\begin{array}{l}\text { Mining is detrimental to the other } \\
\text { developments in Eastern and Northern } \\
\text { Finland (completely disagree - completely } \\
\text { agree) }\end{array}$ & $\begin{array}{l}\text { Correlation } \\
\text { Significance (2-way) } \\
\text { N }\end{array}$ & $\begin{array}{l}-.330 \\
.000 \\
291\end{array}$ & $\begin{array}{l}-.426 \\
.000 \\
291\end{array}$ & $\begin{array}{l}-.229 \\
.000 \\
291\end{array}$ \\
\hline
\end{tabular}


The variables regarding knowledge of mining and familiarity with metal ore mines in Finland are related to the acceptability of mining for certain substances in Finland. People who are more familiar with metal ore mines operating in Finland also accept mining for uranium and for metals and minerals in Finland more readily (correlations $0.155-0.194, \mathrm{p}<0.01$ ). The connection remains moderate for attitudes to uranium, but for metals and minerals the connection is approaching strong. Another variable belonging to this group, sufficient knowledge of mining, is also connected to the acceptability of mining for uranium in Finland. The respondents in Lapland who perceive themselves to be sufficiently well informed about mining accept mining for uranium more readily $(0.151, \mathrm{p}=0.01)$. The connection observed is moderate. (see Table 6)

The variables stressing the drawbacks and necessity of mining for Eastern and Northern Finland are strongly connected to the acceptability of mining for the substances studied. Respondents in Lapland stressing the drawbacks are less ready to accept mining for uranium, metals and minerals and also aggregates and natural stones in Finland as a whole (correlations from -0.229 to $-0.426, \mathrm{p}<0.001$ ), and those stressing necessity are more willing to accept mining for these substances (correlations $0.218-0.452, \mathrm{p}<0.001$ ). The result is fairly clear and even obvious. (see Table 7)

Table 7. Correlation between trust in environmental legislation and officialdom and acceptability

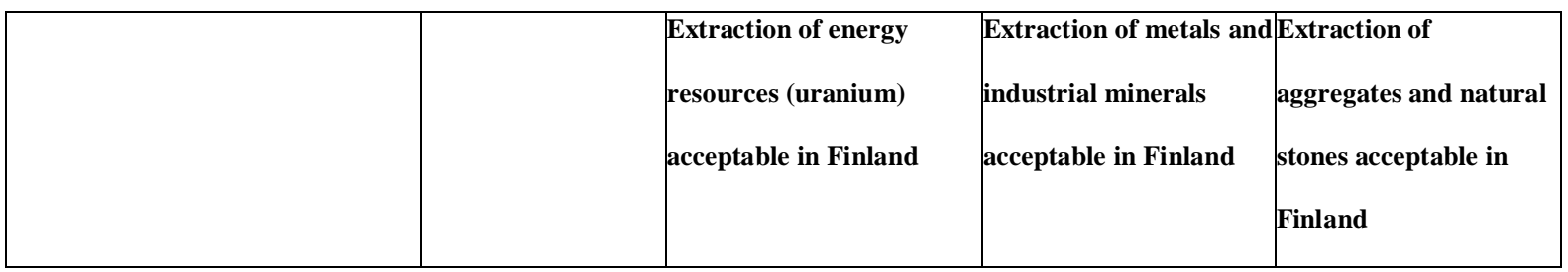




\begin{tabular}{|c|c|c|c|c|}
\hline $\begin{array}{l}\text { In Finland the officials reliably } \\
\text { monitor the environmental effects } \\
\text { of mining (completely disagree - } \\
\text { completely agree) }\end{array}$ & $\begin{array}{l}\text { Correlation } \\
\text { Significance (2-way) }\end{array}$ & $\begin{array}{l}.411 \\
.000 \\
292\end{array}$ & .376 & $\begin{array}{l}.184 \\
.002 \\
292\end{array}$ \\
\hline $\begin{array}{l}\text { Environmental legislation } \\
\text { guarantees that mining will not } \\
\text { cause significant environmental or } \\
\text { health hazards } \\
\text { (completely disagree - completely } \\
\text { agree) }\end{array}$ & $\begin{array}{l}\text { Correlation } \\
\text { Significance (2-way) }\end{array}$ & .372 & .412 & .207 \\
\hline
\end{tabular}

Respondents' trust in the environmental legislation and officialdom are related to the acceptance of mining for all types of substances examined. The correlations are mostly highly statistically significant. They are strong with the exception of one moderate correlation. With one exception the strengths of the correlations are over 0.2 and statistically highly significant $(\mathrm{p}<0.001)$. Only the correlation between the acceptability of quarrying for aggregates and natural stones at the level of Finland as a whole and trust in monitoring by officialdom is under 0.2 . Yet this correlation is still close to 0.2 and statistically significant $(p<0.01)$. The outcome is largely as expected. If people trust the environmental legislation and officialdom in matters pertaining to mining, it is easier for them to accept mining which is strictly controlled by the legislation and permitting. The examination of Lapland revealed nothing new in regard to these correlations; they are much the same as in the region of Kainuu. (see Table 8)

Table 8. Correlation between accepting operations of foreign mining companies and accepting mining for different substances

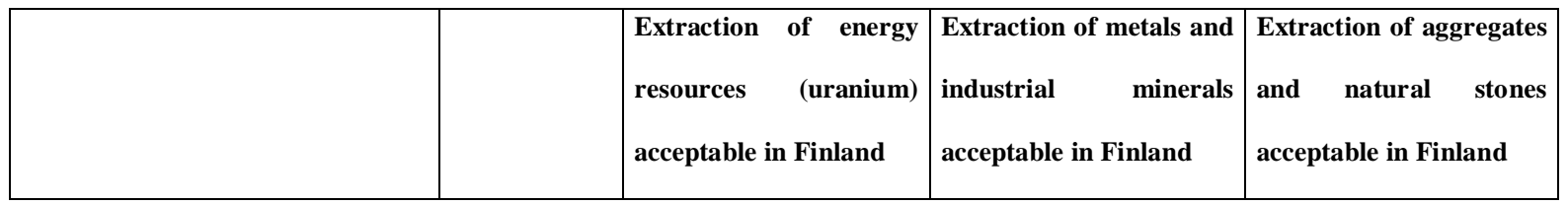




\begin{tabular}{|l|l|l|l|l|}
\hline Foreign mining companies' & Correlation & .327 & .279 & .095 \\
operations acceptable in Finland & Significance & & & \\
(completely disagree - completely & $(2$-way) & .000 & .000 & .106 \\
agree) & $\mathrm{N}$ & 293 & 293 & 293 \\
\hline
\end{tabular}

In Lapland there is a positive and fairly strong correlation between accepting the operations of foreign mining companies in Finland with both mining for uranium and for metals and industrial minerals (correlations over 0.25 and statistically highly significant $\mathrm{p}<0.001$ ). No statistically significant or very large correlation is to be found with accepting quarrying for aggregates and natural stones (correlation 0.095, p>0.05). In Lapland, the pattern is the same as in Kainuu. (see Table 8)

\section{Summary of research findings}

The findings of our study show that wider environmental attitudes and especially environmental concern are connected to the acceptability of mining for certain types of extractives. In neither of the regions targeted in the correlation analysis of this paper was there a connection between indifferent attitude and deprecating own actions in environmental protection and acceptance of mining for the substances studied (see also Jartti et al. 2014, 109-114, 197). The situation is different in regard to positive attitude to the environment and placing emphasis on environmental protection and caring for the environment. In both regions, very strong and statistically highly significant negative connections are to be found between acceptance of uranium mining and stressing environmental protection. Accordingly, in Lapland statistically significant negative connection can be found between the acceptance of mining for metals and minerals and an attitude stressing environmental protection. No clear connections are to be found between the acceptance of mining for aggregates and natural stones and an attitude stressing environmental protection. This would likely suggest 
that in the targeted regions the extraction of aggregates and natural stones is not deemed to be particularly detrimental to the environment.

The connections between variables having to do with the respondent's knowledge of mining and familiarity with metal ore mines operating in Finland and the acceptability of mining for the substances studied are fairly similar in the two regions. In Kainuu and Lapland the respondent's evaluation of the sufficiency of his/her subjective knowledge of mining is not very clearly connected to the acceptability of mining for the substances studied at the level of Finland as a whole. Familiarity with metal ore mines operating in Finland gives rise to more correlations. Especially in Lapland, there is a statistically significant connection (0.194, $\mathrm{p}=0.001$ ) between familiarity with metal ore mines operating in Finland and acceptance of mining for metals and minerals. Familiarity with metal ore mines operating in Finland is typically correlated most strongly with the acceptance of mining for metals and minerals and uranium. No irrefutable connections are to be found between the acceptability of the extraction of aggregates and natural stones and familiarity with metal ore mines operating in Finland. This is understandable, as respondents were asked about their familiarity specifically with metal ore mines, not about their familiarity with the extraction of aggregates and natural stones.

The variables measuring the way people perceive the drawbacks and benefits of mining for the development of Eastern and Northern Finland maintain their connection to the acceptability of mining in the two regions studied. In both Kainuu and Lapland, those stressing the drawbacks are more negative in their attitudes to the acceptability of mining for the substances studied. The correlations are statistically highly significant. In contrast, those stressing the benefits are more ready to accept the extraction of all the substances studied. 
The study scrutinized trust in officialdom to monitor the environmental effects of mining and the ability of the national legislation to curb significant environmental and health hazards. In the regions of Kainuu and Lapland the correlations between trust in the functionality of monitoring by officialdom, in the environmental legislation and in the acceptance of mining for the substances of interest are positive and mainly strong. Thus, those respondents placing more trust in the environmental legislation and in officialdom are also more tolerant of mining for all the substances of interest in Finland as a whole.

There is a positive relation with the acceptability of mining in regard to the acceptance of the operations of foreign mining companies in Finland. Positive correlations indicate that people who are more inclined to accept the operations of foreign mining companies in Finland are also more inclined to accept mining for uranium and for metals and minerals. The correlations between acceptance of quarrying for aggregates and natural stones and the operations in Finland of foreign mining companies are smaller than for those substances mentioned above. In Kainuu and Lapland these correlations are not very strong, and they seldom reach statistical significance.

\section{Conclusion}

The study addressed the prerequisites of the SLO in mining in two Finnish regions. The aim was to contribute to the gradually increasing body of quantitative research on how the public at large set preconditions for the SLO and how they value certain factors affecting it (Mason et al. 2014; Moffat et al. 2014a; Moffat et al. 2014b; Zhang \& Moffat 2015; Zhang et al. 
2015). Regional acceptance of mining for different substances is seen in this paper as a precondition and a basis for individual SLOs.

The findings show that the six factors investigated are indeed related to acceptance of the mining for the substances studied but not in any straightforward manner. For instance, if a person's attitude towards environmental protection is positive, he/she more easily adopts a negative attitude towards mining for uranium but does not necessarily oppose the extraction of metals and minerals or aggregates and natural stones. In addition to this, acceptance of mining for different extractives may vary depending on the region's economic, cultural and social circumstances.

An interesting phenomenon is that familiarity with metal ore mines appears in some cases to increase, for example, the acceptance of quarrying for metals and minerals and uranium, but subjective knowledge about mining does not appear to be so strongly connected to the acceptance of the different substances mined. Here one might consider whether merely enhancing public awareness of mining is sufficient to influence the acceptability of mining or if it would make more sense also to invest more in enhancing the public's familiarity with individual mines. From a methodological viewpoint, the question concerning familiarity can be interpreted to measure the respondent's conscious relation with mines. In one sense it refers to the idea of being cognizant of mining activities or actors. In another sense, the question can also measure emotion, sensation and even valuation.

However, crucial questions for the mining industry are as follows: How can the familiarity be acquired and what constitutes the familiarity? Is it gained, e.g., through random intercourse with representatives of the mining sector or through organized involvement, engagement and 
participation settings (O'Faircheallaigh \& Corbett 2005; Solomon et al. 2008; Saurugger 2009)? Or should the answer to the question of familiarity be searched for from the perspective of the other meaning of the term? Maybe familiarity is gained through memorable experiences in other types of real-life situations, which are emotionally laden and affectively stimulating. For instance, these types of issues are conceptualized in current tourism research with the term memorable tourism experience (MTE), which has become a focal point for the research field (Tung \& Ritchie 2011; Kim, Ritchie \& McCormick 2012; Kim 2014). Another question behind the familiarity is related to the scale of interaction; besides engagement and interaction procedures, mining companies have started to demonstrate their corporate social responsibility (CSR) programmes and disclose their social and environmental performance via the media (Brown \& Deegan 1998; Jenkins \& Yakovleva 2006; Measham et al. 2013).

Perceiving the advantages and disadvantages of mining is connected to the acceptance of mining for different substances. Jenkins-Smith et al. $(2011,632)$ have stated that, for example, attitudes to potentially hazardous projects are frequently connected to the wider need in society which is felt to exist regarding the project in question. Thus, the more the project is seen to be needed the more acceptable it is felt to be (see also Jenkins-Smith \& Kunreuther 2001, 374-375). Likewise, in this research the acceptability of mining for different kinds of substances would appear to be linked to a wider societal conception of what is needed.

Our results show that institutional-governmental factors and the general trust placed in these are related to the acceptance of the substances of interest, and hence they play a role also in the development of the SLOs. Ethics and perceptions of justice are important in 
contemplating attitude formation by region. As Zhang et al. $(2015,1070)$ have shown, socalled procedural fairness and confidence in governance positively predicts trust in the mining industry, which in turn is connected to the social acceptance of mining.

The increasing debate on resource nationalism (see e.g. Bremmer \& Johnston 2009) guided us to add this factor to our SLO study. An earlier study (Jartti et al. 2014, 160-166) revealed that people seem to be very critically disposed towards the operations of foreign mining companies in Finland. The correlation analysis shed more light on this issue by showing that one prerequisite for SLO seems to be a positive attitude towards foreign mining companies.

With this study we contribute to the novel research on the public attitudes towards mining (e.g. Moffat et al. 2014a; Moffat et al. 2014b; Zhang et al. 2015). Through the findings we gain preliminary information about the relations existing between the SLO and its preconditions, especially in Finland. Quantitative scrutiny of the preconditions and attitudinal factors conditioning the SLO to operate and ascertain the mechanisms is one interesting avenue for future research to operate within the research paradigm of the SLO.

\section{Acknowledgements}

This study is based on three consecutive research projects, which all are joint enterprises between the University of Eastern Finland (UEF) and the University of Jyväskylä (JYU). The SoLiMi (Preconditions and tools for social license to mine, 2013-2015) project is part of the Finnish Funding Agency for Innovation (TEKES) research programme entitled Green Mining. SoLiMi was partly financed also by Regional Council of Lapland, Regional Council of North Karelia, The Finnish Mining Association, Outokumpu, Talvivaara Mining 
Company, Dragon Mining, Inmet Mining, Altona Mining, Endomines, Sotkamo Silver. The foundations of the study were laid on a previous project funded by the Academy of Finland entitled 'Finnish mining communities under global transition: Capacities of local responses' (2010-2012). The on-going project 'Social license to operate: A real tool or rhetoric? Examining the mining industry in Finland, Australia, and Canada' (2015-2017) is part of the Academy of Finland's research programme 'Primary mineral resources'. Support from the Academy of Finland's project no. 253332 is gratefully acknowledged.

\section{References:}

Akiwumi, F.A., 2012. A global incorporation and local conflict: Sierra Leonean mining regions. Antipode. 44(3), 581-600.

Bremmer, I., Johnston, R., 2009. The rise and fall of resource nationalism. Survival: Global Politics and Strategy. 51(2), 149-158. doi: 10.1080/00396330902860884.

Brown, N., Deegan, C., 1998. The public disclosure of environmental performance information: A dual test of media agenda setting theory and legitimacy theory. Acc. and Busin. Res. 29(1), 21-41. doi: 10.1080/00014788.1998.9729564

Cademartori, J., 2002. Impacts of foreign investment on sustainable development in a Chilean mining region. Nat. Res. For. 26(1), 27-44.

Clark, A.L., Cook Clark, J., 1999. The new reality of mineral development: Social and cultural issues in Asia and Pacific Nations. Resour. Policy. 25(3), 189-196.

Eerola, T., 2008. Uranium exploration, non-governmental organizations, and local communities. The origin, anatomy, and consequences of a new challenge in Finland. Estonian J. of Earth Sci., 57, 112-122.

Eerola, T., Ziessler, S., 2013. Kommentti: Sosiaalinen toimilupa kannustaa kaivosyrityksiä yhteiskuntavastuuseen. [Comment: Social licence to operate encourage mining 
enterprises to corporate responsibility, in Finnish] Geologi, 65, 100-105. Available at: http://www.geologinenseura.fi/geologi-lehti/4-2013/Geologi_4_2013_kommentti.pdf (accessed 05.03.2014).

Everingham, J.-A., 2012. Towards social sustainability of mining: The contribution of new directions in impact assessment and local governance. Gre. Man. Int. 57, 91-103.

Fast Consulting, (2013). Situation Summary: Public Support for the Continuation of the Uranium Mining Industry in Saskatchewan. Prepared for Areva Resources. Available at: http://us.areva.com/home/liblocal/docs/Operations/Mining/Situation\%20Summary\%20 AREVA\%20Nov2013-WEB.pdf (accessed 25.05.2015).

Finland's Minerals Strategy, 2010. Finland's Minerals Strategy. The Geological Survey of Finland. Available at: http://projects.gtk.fi/export/sites/projects/minerals_strategy/documents/FinlandsMineral sStrategy_2.pdf (accessed 05.02.2015).

Franks, D.M., Cohen, T., 2012. Social licence in design: Constructive technology assessment within a mineral research and development institution. Techn. Forec. and Soc. Change. 79, 1229-1240.

Franks, D., Cohen, T., McLellan, B., Brereton, D., 2010. Technology Futures Discussion Paper: Technology Assessment and the CSIRO Minerals Down Under National Research Flagship. Cluster research report No. 2.1., Centre for Social Responsibility in Mining, Sustainable Minerals Institute, The University of Queensland, For: CSIRO Minerals Down Under National Research Flagship. Available at: http://webcache.googleusercontent.com/search?q=cache:9L_Gf2ZyToJ:www.csiro.au/Organisation-Structure/Flagships/Minerals-Down-UnderFlagship/mineral-futures/mineral-futures-collaboration-cluster/Technology-futuresdiscussion-paper.asp $\mathrm{x}+\& \mathrm{~cd}=1 \& \mathrm{hl}=\mathrm{en} \& \mathrm{ct}=\mathrm{clnk}($ accessed 5.3.2014). 
Gibson, R.B., 2006. Sustainability assessment and conflict resolution: Reaching agreement to proceed with the Voisey's Bay nickel mine. J. of Clean. Prod. 14(3-4), 334-348.

Gunningham, N., Kagan, R.A., Thornton, D., 2004. Social license and environmental protection: Why businesses go beyond compliance. Law and Soc. Inq. 29(2), 307-341.

Hernesniemi, H., Berg-Andersson, B., Rantala, O., Suni, P. 2011. Kalliosta kullaksi, kummusta klusteriksi: Suomen mineraaliklusterin vaikuttavuusselvitys. [From Rock to Gold, from Hill to Cluster: Finland's Mineral Cluster's Effectiveness Report, in Finnish] Research Institute of the Finnish Economy, ETLA B252. Taloustieto Ltd., Helsinki.

Hilson, G., 2002. An overview of land use conflicts in mining communities. Land Use Policy. 19(1), 65-73.

Holden, W.N., Jacobson, R.D., 2007. Mining amid armed conflict: Nonferrous metals mining in the Philippines. The Can. Geo. 51(4), 475-500.

Holden, W.N., Jacobson, R.D., Moran, K., 2007. Civil society opposition to nonferrous metals mining in Montana. Int. J. of Vol. and Non-Profit Org (Voluntas). 18(3), 266292.

Holden, W.N., Jacobson, R.D., 2008. Civil society opposition to nonferrous metals mining in Guatemala. Int. J. of Vol. and Non-Profit Org (Voluntas). 19(4), 325-350.

IIED, 2002. Breaking New Ground: Mining, Minerals, and Sustainable Development. The Report of the MMSD project. Earthscan Publications. London.

Jartti, T., Rantala, E., Litmanen, T., 2014. Sosiaalisen toimiluvan ehdot ja rajat: Uudenmaan, Pohjois-Karjalan, Kainuun ja Lapin maakuntien asukkaiden näkemykset kaivannaistoiminnan hyväksyttävyydestä. [Preconditions and Limits of the Social Licence to Operate: Views of Residents of Uusimaa, North-Karelia, Kainuu and 
Lapland on the Acceptability of Mining, in Finnish] SoPhi no. 126, Jyväskylä. Available at: https://jyx.jyu.fi/dspace/handle/123456789/44460 (accessed 05.02.2015).

Jartti, T., Sairinen, R., Litmanen, T., 2012. Kaivosteollisuus kansalaisten arvioinnissa: Millaisen kaivosalan maakuntien asukkaat haluavat? [Mining industry in citizens' evaluation: What kind of mining industry do the regions' citizens want?] Maaseudun Uusi Aika, 20(2), 48-58.

Jenkins, H., Yakovleva, N., 2006. Corporate social responsibility in the mining industry: Exploring trends in social and environmental disclosure. J. of Clean. Prod. 14(3-4), 271-284. doi:10.1016/j.jclepro.2004.10.004

Jenkins-Smith, H., Kunreuther, H., 2001. Mitigation and benefits measures as policy tools for siting potentially hazardous facilities: Determinants of effectiveness and appropriateness. Risk Analysis. 21(2), 371-382.

Jenkins-Smith, H.C., Silva, C.L., Nowlin, M.C., deLozier, G., 2011. Reversing nuclear opposition: Evolving public acceptance of a permanent nuclear waste disposal facility. Risk Analysis. 31(4), 629-644.

Joyce, S., Thomson, I., 2000. Earning a social licence to operate: Social acceptability and resource development in Latin America. The Canadian Mining and Metallurgical Bulletin, 93(1037). Available at: http://oncommonground.ca/wpcontent/downloads/license.htm (accessed 6.8.2013).

Kim, J.-H., 2014. The antecedents of memorable tourism experiences: The development of a scale to measure the destination attributes associated with memorable experiences. Tourism Management 44(October), 34-45. doi:10.1016/j.tourman.2014.02.007 
Kim, J.-H., Ritchie, B.J.R., McCormick, B., 2012. Development of a Scale to Measure Memorable Tourism Experiences. J. of Trav. Res. 51(1), 12-25. doi: $10.1177 / 0047287510385467$

Kokko, M., 2013. Kaivosteollisuus. Toimialaraportti 3/2013. [The Mining Industry. Branch of Industry Report 3/2013, in Finnish] Ministry of Employment and the Economy. Available at: http://www.temtoimialapalvelu.fi/files/1949/Kaivosteollisuus_2013.pdf_2_versio.pdf (accessed 14.05.2014).

Kuisma, M., 1985. Outokumpu 1910-1985. Kuparikaivoksesta suuryhtiöksi. [Outokumpu 1910-1985: from Copper Mine to Grand Company, in Finnish] Outokumpu Oy, Forssa.

Kuisma, M., 1989. A History of Outokumpu. Gummerus, Jyväskylä.

Kuisma, M., 1997. Kylmä sota, kuuma öljy. Neste, Suomi ja kaksi Eurooppaa. [Cold War, Hot Oil: Neste, Finland and two Europes, in Finnish] WSOY, Porvoo.

Kuisma, M., 2004. Kahlittu raha, kansallinen kapitalismi. Kansallis-Osake-Pankki 19401995. [Fettered Money, National Capitalism: Kansallis-Osake-Pankki 1940-1995, in Finnish]. Suomalaisen kirjallisuuden seura, Helsinki.

Kuisma, M., 2013. Suomen poliittinen taloushistoria 1000-2000. [History of Finnish Political Economy 1000-2000, in Finnish] Siltala, Helsinki.

Le Billion, P., Levin, E., 2009. Building peace with conflict diamonds? Merging security and development in Sierra Leone. Dev. and Change. 40(4), 693-715.

Lindborg, T., 1996. Suomalaisen kaivosklusterin rakennemuutos. [Structural Change of the Finnish Mining Cluster, in Finnish] Studies of the Department of Economics No. 36, University of Oulu, Oulu. 
Luning, S., 2012. Corporate social responsibility (CSR) for exploration: Consultants, companies and communities in processes of engagements. Resour. Policy. 37(2), 205211.

Martinez-Fernandez, C., Wu, C.-T., Schatz, L.K., Taira, N., Vargas-Hernández, J.G., 2012. The Shrinking mining city: Urban dynamics and contested territory. Int. J. of Urban and Reg. Res. 36(2), 245-260.

Mason, C.M., Paxton, G., Parsons, R., Parr, J.M., Moffat, K., 2014. "For the benefit of Australians": Exploring national expectations of the mining industry. Resour. Policy. $41,1-8$.

Measham, T.G., Mckenzie, F.H., Moffat, K., Franks, D.M., 2013. An expanded role for the mining sector in Australian society? Rural Society 22(2), 184-194. doi: $10.5172 /$ rsj.2013.22.2.184

MEE, 2010. Älykäs ja vastuullinen luonnonvaratalous. Valtioneuvoston luonnonvaraselonteko eduskunnalle [Intelligent and Responsible Natural Resource Economy: Council of State's Natural Resource Report to Parliament, in Finnish]. Ministry of Employment and the Economy Publications, Energy and Climate 69/2010. Available at: http://www.tem.fi/files/28516/TEM_69_2010_netti.pdf (accessed 12.08.2013).

MEE, 2013. Suomi kestävän kaivannaisteollisuuden edelläkävijäksi -toimintaohjelma.

[Finland's Road Map to Sustainable Mining, in Finnish]. Ministry of Employment and the Economy Publications. Available at: 15/2013.http://www.tem.fi/files/36550/TEMjul_15_2013_web_29042013.pdf (accessed 15.08.2013).

Moffat, K., Zhang, A., 2014. The paths to social licence to operate: An integrative model explaining community acceptance of mining. Resour. Policy. 39, 61-70. 
Moffat, K., Zhang, A., Boughen, N., 2014a. Australian attitudes toward mining: Citizen survey - 2014 results. CSIRO, Australia. EP 146276. Available at: http://people.csiro.au/ /media/People\%20Finder/M/K/KierenMoffat/CSIRO_MiningReport_Aus.ashx. (accessed 24.08.2015).

Moffat, K., Boughen, N., Zhang, A., Lacey, J., Fleming, D., Uribe, K., 2014b. Chilean Attitudes toward Mining: Citizen Survey - 2014 Results. CSIRO, Australia. EP 147205. Available at: http://www.csiro.au/ /media/MRF/Files/Chile/EN-CSIROMiningReport-Chile-WEB.pdf. (accessed 24.8.2015).

Mononen, T., 2012. Kaivostoiminnan luonnonvara- ja ympäristökysymykset maaseudulla. Esimerkkinä Pampalon kultakaivos. [Natural resource and environmental questions in the case of mining in rural areas: Pampalo as an example, in Finnish]. Maaseudun Uusi Aika. 20(2), 21-36.

O'Faircheallaigh, C., Corbett, T., 2005. Indigenous participation in environmental management of mining projects: The role of negotiated agreements. Env. Pol., 14(5), 629-647, DOI: 10.1080/09644010500257912

Owen, J.R., Kemp, D., 2013. Social licence and mining: A critical perspective. Resour. Policy. 38(1), 29-35.

PDAC (Prospectors and Developers Association of Canada), 2009. Public Opinion Survey. Available at: http://www.pdac.ca/docs/default-source/public-affairs/fact-sheet-publicopinion-survey.pdf?sfvrsn=6 (accessed 20.05.2015).

Prno, J. 2013. An analysis of factors leading to the establishment of a social licence to operate in the mining industry. Resour. Policy. 38(4), 577-590.

Prno, J., Slocombe, D.S., 2012. Exploring the origins of "social license to operate" in the mining sector. Perspectives from governance and sustainability theories. Resour. Policy. 37(3), 346-357. 
Richards, J.P., 2009. Introduction. In Richards, J.P., (Eds.), Mining, Society and a Sustainable World. Springer, Berlin, xxi-xxv.

Sacome (The South Australian Chamber of Mines and Energy), 2014. Uranium and Nuclear Attitudes Survey. Available at: http://www.sacome.org.au/images/UAS_Results_summary_final.pdf (accessed 25.05.2015).

Saskatchewan Mining Association, 2013. 2012 Public Opinion Survey Results. Fast Consulting. Available at: http://www.saskmining.ca/uploads/news_files/95/doug-fastsma-2012-public-survey-results.pdf (accessed 20.05.2015).

Saurugger, S., 2009. The social construction of the participatory turn: The emergence of a norm in the European Union. European J. of Pol. Res. 49: 471-495. doi: 10.1111/j.1475-6765.2009.01905.x

Sitra, 2009. A Natural Resource Strategy for Finland: Using Natural Resources Intelligently. Available at: http://www.sitra.fi/julkaisut/muut/A\%20Natura1\%20Resource\%20Strategy\%20for\%20 Finland.pdf (accessed 06.02.2015).

Slack, K., 2009. The role of mining in the economies of developing countries: Time for a new approach. In: Richards, J.P. (Eds.), Mining, Society and a Sustainable World. Springer, Berlin. 75-90.

Solomon, F., Katz, E., Lovel, R., 2008. Social dimensions of mining: Research, policy and practice challenges for the minerals industry in Australia. Resour. Policy. 33(3), 142149.

Särkikoski, T., 2005. Outo malmi - jalo teräs: Outokummun tie ruostumattomaan teräkseen [Strange Ore - Noble Steel: The Road of Outokumpu to Stainless Steel, in Finnish]. Outokumpu, Espoo. 
Taylor, L., 2011. Environmentalism and social protest: The contemporary anti-mining mobilization in the province of San Marcos and the Condebamba Valley, Peru. J. of Agr. Ch. 11(3), 420-439.

Thomson, I., Boutilier, R.G., 2011a. Social license to operate. In Darling, P. (Eds.) SME mining engineering handbook. Third edition. Volume 2. Society for Mining, Metallurgy, and Exploration, Inc. United States. 1779-1796.

Thomson, I., Boutilier, R.G., 2011b. Modelling and measuring the social license to operate: Fruits of a dialogue between theory and practice. Available at: http://socialicense.com/publications.html (accessed 05.03.2014).

Thomson, I., Joyce, S., 2008. The social licence to operate: what it is and why does it seem so difficult to obtain? Presentation at PDAC Convention, Toronto. Available at: http://oncommonground.pubco.net/wpcontent/downloads/PDAC_2008_Social_Licence.pdf (accessed 20.08.2013).

Trebeck, K.A., 2007. Tools for the disempowered? Indigenous leverage over mining companies. Aust. J. of Pol. Sci. 42(4), 541-562.

Törmä, H., Reini, K., 2009. Suomen kaivosalan aluetaloudelliset vaikutukset elinkeinorakenteeseen ja työllisyyteen. [Finland's Mining Sector's Regional Economic Effects on Business Structure and Employment, in Finnish] Reports No. 37, University of Helsinki, Ruralia Institute. Available at: http://www.helsinki.fi/ruralia/julkaisut/pdf/Raportteja37.pdf (accessed 24.10.2013).

Tung, V.W.S., Ritchie, B.J.R., 2011. Exploring the essence of memorable tourism experiences. Annals of Tourism Res. 38(4), 1367-1386.

doi:10.1016/j.annals.2011.03.009 
Tuusjärvi, M., 2013. From a Mine to You: Sustainability of the Finnish Mining Sector in the Context of Global Supply Chains of Metals. Dissertation. University of Helsinki, Department of Geosciences and Geography, A23.

Urkidi, L., 2011. The defence of community in the anti-mining movement of Guatemala. J. of Agr.Ch. 11(4), 556-580.

Uusisuo, M., 2012a. Suomen kaivostoiminta ja kaivoshankkeet. [Finland's Mining Activity and Mining Projects, in Finnish] In: Loukola-Ruskeeniemi, K. (Eds.), Suomen kaivosteollisuuden tilannekatsaus vuonna 2012 [Finland's Mining Industries State-ofthe-art Review, in Finnish]. Ministry of Employment and Economy reports 23/2012, 616. Available at: http://www.tem.fi/files/34066/TEMrap_23_2012.pdf (accessed 22.08.2013).

Uusisuo, M., 2012b. Kaivosteollisuus. [Mining Industry, in Finnish] Branch of industry report 2/2012. Ministry of Employment and the Economy. Available at: http://www.temtoimialapalvelu.fi/files/1605/Kaivosteollisuus2012_web.pdf (accessed 24.10.2013).

Wilburn, K.M., Wilburn, R., 2011. Achieving social license to operate using stakeholder theory. J. of Int. Bus. Ethics, 4(2), 3-16.

Wilson, L.J., 2004. Riding the resource rollercoaster: Understanding socioeconomic differences between mining communities. Rural Sociology. 69(2), 261-281.

World Bank Institute, 2014. Public Perceptions Survey on Extractive Industries. Governance for Extractive Industries Program. Available at: http://www.surveyextractives.com/extractives/ (accessed 20.05.2015).

Zhang, A., Moffat, K., 2015. A balancing act: The role of benefits, impacts and confidence in governance in predicting acceptance of mining in Australia. Resour. Policy. 44, 25-34. 
Zhang, A., Moffat, K., Lacey, J., Wang, J., González, R., Uribe, K., Cui, L., Dai, Y., 2015. Understanding the social licence to operate of mining at the national scale: A comparative study of Australia, China and Chile. J. of Clean. Prod. 108, 1063- 1072.

Ziessler-Korppi, S., 2013. Local Stakeholder Engagement of Mineral Exploration Companies within the Corporate Social Responsibility (CSR) Framework: Insights into Companies Operating in Northern Finland. Aalto University, School of Science. Available at: http://projects.gtk.fi/export/sites/projects/kaivosakatemia/dokumentit/ZiesslerKorppi_Sofia_masters_thesis.pdf (accessed 05.02.2015) 